\title{
Model Pembelajaran Inquiry Terbimbing Terintegrasi Laboratorium Virtual untuk Meningkatkan Pemahaman Konsep dan Keterampilan Metakognitif Siswa
}

\author{
${ }^{1 a}$ Muhali, ${ }^{2 b *}$ Muhammad Asy'ari, ${ }^{3}$ Roniati Sukaisih \\ ${ }^{1 a}$ Program Studi Pendidikan Kimia, FSTT; ${ }^{2 b}$ Program Studi Pendidikan Olahraga dan \\ Kesehatan, FIKKM Universitas Pendidikan Mandalika, Jl. Pemuda No. 59A Mataram 83125, \\ Indonesia. \\ ${ }^{3}$ Madrasah Aliyah Negeri 3 Lombok Tengah, Sengkol-Pujut, Lombok Tengah, Indonesia \\ *Email Korespondensi: muhammadasyari@undikma.ac.id
}

\begin{abstract}
Abstrak
Penelitian ini bertujuan untuk mengetahui efektivitas model pembelajaran inquiry terintegrasi laboratorium virtual terhadap pemahaman konsep dan keterampilan metakognitif siswa. Quasi eksperimen dengan nonequivalent control group design digunakan dalam penelitian ini. Sampel penelitian ini adalah 56 siswa yang terbagi ke dalam 2 (dua) kelas parallel yang dipilih menggunakan cluster random sampling technique. Instrumen yang digunakan berupa tes pemahaman konsep dan instrumen lembar penilaian (LP) keterampilan metakognitif yangtelah dinyatakan valid dan reliabel. Data penelitian dianalisis secara deskriptif menggunakan persamaan $\mathrm{n}$-gain dan statistic dengan bantuan software IBM SPSS 23 Version. Hasil penelitian menunjukkan bahwa pemahaman konsep siswa pada kelompok eksperimen (mean= 79,19; n-gain= 0,76 dengan kategori tinggi) lebih baik dari kelompok kontrol (mean $=43,08 ; n$-gain $=0,36$ dengan kategori sedang) dan berbeda secara signifikan $(p<0.05)$. Keterampilan metakognitif siswa menunjukkan hal serupa, kelompok eksperimen (pertemuan $I=54,69$ (pertemuan $\mathrm{II}=67,86$; pertemuan $\mathrm{II}=79,24$ ) ditemukan lebih baik dari kelompok control (pertemuan $\mathrm{I}=46,09$; pertemuan $\mathrm{II}=$ 53,01 ; dan pertemuan III 55,13 ). Hasil penelitian menunjukkan model pembelajaran inquiry terbimbing terintegrasi laboratorium virtual efektif dalam meningkatkan pemahaman konsep dan keterampilan metakognitif siswa dalam pembelajaran kimia materi larutan penyangga.
\end{abstract}

Kata kunci: Model Guided Inquiry; Laboratorium Virtual; Pemahaman Konsep; Keterampilan Metakognitif

\section{Virtual Laboratory Integrated Guided Inquiry Learning Model to Improve Students' Concept Understanding and Metacognitive Skills}

\begin{abstract}
This study aims to determine the effectiveness of the virtual laboratory integrated guided-inquiry learning model on students' concept understanding and metacognitive skills. Quasi experimental with nonequivalent control group design was used in this study. The sample of this study was 56 students who were divided into 2 (two) parallel classes which were selected using the cluster random sampling technique. The instruments used were in the form of a concept understanding test and a metacognitive skill assessment sheet $(L P)$ which had been declared valid and reliable. The research data were analyzed descriptively using the $n$-gain equation and statisticaly with the help of IBM SPSS 23 Version software. The results showed that students' concept understanding in the experimental group (mean = 79.19; $n$-gain $=0.76$ in the high category) was better than the control group (mean = 43.08; $n$-gain $=0.36$ in the medium category) and significantly different $(p<0.05)$. Students' Metacognitive skills showed the same thing, the experimental group (meeting I= 54.69; meeting II=67.86; meeting III =79.24) was found to be better than the control group (meeting I= 46.09; meeting II = 53, 01, and meeting III = 55.13). The results showed that the virtual laboratory integrated guided-inquiry learning model was effective in improving students' concept understanding and metacognitive skills in buffer solution chemistry learning subject.
\end{abstract}

Keywords: Guided Inquiry Learning Model; Virtual Laboratory; Concept Understanding; Metacognitive Skills

How to Cite: Muhali, M., Asy'ari, M., \& Sukaisih, R. (2021). Model Pembelajaran Inquiry Terbimbing Terintegrasi Laboratorium Virtual untuk Meningkatkan Pemahaman Konsep dan Keterampilan Metakognitif Siswa. Empiricism Journal, 2(2), 73-84. https://doi.org/10.36312/ej.v2i2.594

\section{PENDAHULUAN}

Ilmu kimia secara umum merupakan ilmu yang mempelajari tentang alam dan secara khusus mempelajari struktur dan susunan, sifat dan perubahan materi, seerta energi yang 
menyertai perubahannya. IImu kimia mengkaji aspek secara abstrak dan konkret dalam satu kesatuan (Adnyana, 2012), pemahaman konsep kimia melibatkan kajian aspek makroskopik, mikroskopik, dan simbolis (Sudria et al., 2011), dan dalam ilmu kimia dipelajari tentang fakta, konsep dan prinsip (Sukmawati, 2019). Kimia sebagai mata pelajaran yang diterima secara universal dan direalisasikan tidak hanya oleh siswa tetapi juga orang-orang yang ingin tahu tentang bahan kimia. Mata pelajaran ini memberikan pengetahuan yang lebih luas tentang sains secara umum yang wajib bagi setiap individu yang bertujuan untuk mempelajari lingkungan (Hassan, 2015). Dengan demikian, ilmu kimia perlu dibelajarkan kepada siswa agar memahami konsep secara mikroskopik untuk menjelaskan fenomena makroskopik dan penggunaan simbolik dalam kimia, sehingga kajian konsep tentang fakta, konsep dan prinsip kimia secara abstrak dan konkret dapat dikuasai siswa.

Keberhasilan pembelajaran bagi siswa menjadi tujuan utama pendidikan (Muhali et al., 2020), dan sampai saat ini pendidik sebagai fasilitator pembelajaran masih menuntut siswa mampu menguasai pengetahuan secara kognitif (Sukaisih \& Muhali, 2014), pembelajaran kimia seharusnya memperhatikan beberapa hal dilihat dari karakteristik ilmu kimia itu sendiri baik dari aspek proses, produk, dan sikap (Sukmawati, 2019). Kenyataan lapangan menunjukkan bahwa variabel yang mempengaruhi lemahnya pengajaran sains khususnya kimia yaitu sikap negatif siswa terhadap subjek sains, metodologi yang digunakan pendidik, tidak adanya materi instruksional dalam ilmu ajar, atau kurangnya inspirasi atau fondasi akan konsep di kalangan siswa (Hassan, 2015). Pembelajaran kimia berorientasi pada produk tanpa memperhatikan aspek sikap dan proses (Sukmawati, 2019), pembelajaran kimia di kelas kurang mengintegrasikan tigas aspek ilmu kimia (makroskopik, mikroskopik, dan simbolik) (Adnyana, 2012). Hal ini berakibat pada siswa dalam memahami pembelajaran kimia yang terkesan sulit, tidak kontekstual, dan sangat abstrak. Pembelajaran kimia dalam prosesnya siswa kurang terlibat secara aktif dalam proses berpikir, pencarian dan penggunaan informasi, dan rendahnya pengembangan analisis-kritis, pemecahan masalah, dan kontrol terhadap kemampuan berpikirnya yang berakibat pada rendahnya pemahaman konsep dan keterampilan metakognitif siswa. Menurut Muhali (2019) pendidikan di abad 21 menuntut siswa dalam pembelajaran khususnya kimia dapat menguasai sejumlah pengetahuan yang kompleks disertai berbagai keterampilan baik keterampilan berpikir tingkat tinggi, keterampilan menggunakan informasi, maupun teknologi.

Hasil studi awal menunjukkan bahwa pencapaian pemahaman konsep siswa sebagian besar di bawah KKM (70) sehingga masih banyak siswa yang belum mencapai ketuntasan secara klasikal. Hal ini mengindikasikan bahwa pemahaman konsep siswa masih rendah, dikarenakan siswa dalam pembelajaran cenderung menghafal, siswa kesulitan dalam mengulang (mengungkap kembali), rendahnya kemampuan mengidentifikasi, menerapkan konsep, fakta, dan prosedur. Upaya yang selama ini dilakukan untuk meningkatkan pemahaman konsep belum diterapkan secara maksimal, pembelajaran cenderung mengarahkan siswa dalam mengingat dan mengulang konsep, sehingga pengetahuan yang diperoleh mudah dilupakan.

Pemahaman konsep pada tataran siswa di sekolah menengah khususnya SMA/MA merupakan hal penting dibelajarkan mengingat tuntutan dalam kerangka kurikulum SMA/SMA yang menekankan pada penguasaan pengetahuan secara konseptual, faktual, prosedural, metakognitif (Kemendikbud, 2013). Siswa dengan pemahaman konsep yang baik dapat mengimplementasikan pengetahuannya secara faktual dalam berbagai situai dan keadaan permasalahan pembelajaran, dan juga menggunakan pengetahuannya dalam menyelesaikan setiap permasalahan melalui berbagai prosedur dengan melibatkan serangkaian aktivitas dalam regulasi pengetahuan yang dimilikinya. Namun sampai saat ini, walaupun aspek kognitif menjadi penekanan utama keberhasilan pembelajaran, tidak jarang siswa hanya menguasai konsep sebatas menghafal, kemudian mengingat kembali, dan menjelaskan pada level pemahaman. Ketika dihadapkan pada tingkatan kemampuan analisis, evaluasi dan mencipta, kebanyakan siswa tidak dapat menyelesaikannya dengan baik.

Hasil observasi bersama guru mata pelajaran kimia di kelas XI IPA SMAN 1 Praya Timur tahun pelajaran 2019/2020 pada pembelajaran materi asam basa, hidrolisis dan penyangga, siswa dibelajarkan melalui penjelasan konsep, diberikan contoh soal, selanjutnya disajikan soal latihan untuk dikerjakan. Tolok ukur keberhasilan siswa didik menurut guru adalah mampu menyelesaikan soal-soal latihan yang diberikan dengan baik. Namun faktanya, ketika 
materi ini diujikan (ujian formatif) rata-rata skor yang diperoleh sebesar 56,78 untuk kelas XI $\mathrm{IPA}_{1}, 62,50$ untuk kelas XI IPA , dan 61,70 untuk kelas XI IPA 3 . Hasil ini untuk ketiga kelas masih berada di bawah KKM (70) sehingga secara klasikal siswa belum mencapai ketuntasan $(\geq 85 \%$ siswa mencapai nilai di atas KKM). Fakta ini membuktikan bahwa siswa tidak benarbenar memahami konsep materi yang dibelajarkan, dan konsep yang dibelajarkan bersifat sementara. Hasil penelitian yang dilakukan Adnyana (2012) membelajarkan pemahaman konsep dengan model siklus belajar hipotesis deduktif, hasil penelitian menunjukkan bahwa pembelajaran ini menghasilkan pemahaman konsep yang lebih baik bagi siswa. Namun dalam pembelajaran yang diterapkan agar lebih optimal dalam pembelajaran sebaiknya dipertimbangkan hal-hal: (1) penyajian fenomena yang lebih bervariasi, (2) menawarkan gagasan yang actual dan kontekstual, (3) memberikan kesempatan yang luas untuk melakukan percobaan, (4) memfasilitasi siswa mempresentasikan atau mendiskusikan hasil percobaan, dan (5) melakukan bimbingan berkelanjutan. Maharani et al. (2013) tentang analisis pemahaman konsep siswa, sebagian kecil siswa dapat menyatakan ulang suatu konsep (11,11\%), kemampuan memberikan contoh dan bukan contoh $(48,15 \%)$, kemampuan mengklasifikasi objek berdasarkan sifat tertentu sesuai dengan konsep (59,26\%), dan kemampuan menyatakan konsep dalam berbagai bentuk representasi $(66,67 \%)$. Rusminiati et al. (2015) yang membelajarkan pemahaman konsep kimia menggunakan model project based learning $(\mathrm{PjBL})$ dan discovery learning $(\mathrm{DL})$ dengan pencapaian rata-rata pemahaman konsep siswa yang dibelajarkan dengan $\mathrm{PjBL}=73,935$ dan pembelajaran $\mathrm{DL}=66,343$ dengan nilai $\mathrm{N}$-gain keduanya dalam kategori sedang. Pencapaian pada setiap indikator menunjukkan pembelajaran dengan DL indikator seperti meringkas, memberi contoh, membandingkan, memprediksi, dan interpretasi masing tergolong rendah, sedangkan pembelajaran dengan PjBL pencapaian indikator meringkas dan membandingkan masih dalam kategori cukup. Dengan demikian, pemahaman konsep secara terus-menerus harus ditekankan pengajarannya kepada siswa.

Pengajaran konsep yang baik seiring dengan pembelajaran siswa atas serangkaian aktivitas atau keterampilan untuk memperoleh dan memahami konsep secara mendalam. Fakta lapangan menunjukkan bahwa upaya pembelajaran yang menekankan pada keterampilan proses siswa kurang dikembangkan, pembelajaran kurang melibatkan kemampuan berpikir siswa dan pembelajaran cenderung berpusat pada pendidik (teacher centered), pemilihan atau implementasi upaya pembelajaran yang menekankan pada serangkaian keterampilan proses siswa seperti praktikum kurang dilakukan. Menurut Hassan (2015) lemahnya kinerja siswa dalam pembelajaran kimia disebabkan karena: (1) kurangnya motivasi dari guru (72\%), (2) kurang lengkapnya sarana laboratorium $(53,3 \%),(3)$ kurangnya buku teks mata pelajaran kimia $(62,7 \%)$, (4) permasalahan bahasa yang digunakan guru $(61,1 \%),(5)$ kurangnya guru kimia $(38,6 \%),(6)$ kesulitan guru dalam menggunakan metode pembelajaran $(54,6 \%)$, (7) kurangnya perhatian guru $(53,3 \%)$, (8) terlalu banyak mata pelajaran (56\%), (9) perangkat kurang lengkap (34,7\%), (10) kelas terlalu besar $(68 \%)$. Selanjutnya, menurut Hassan (2015) tentang tanggapan guru sains terhadap kelengkapan laboratorium, sebanyak 4,4\% guru menyatakan laboratorium telah dilengkapi dengan baik, $28,9 \%$ guru menyatakan laboratorium cukup lengkap, dan 66,7\% guru menyatakan laboratorium tidak dilengkapi dengan baik. Faktor-faktor lain yang mempengaruhi kinerja guru di antaranya: (1) kesulitan dalam penggunaan teknik mengajar (55,6\%), (2) cakupan silabus yang kurang baik (60\%), (3) administrasi sekolah yang kurang baik (40\%), (4) latar belakang siswa yang buruk $(55,6 \%),(5)$ upah rendah $(77,8 \%),(6)$ kurangnya pengalaman mengajar $(44,4 \%),(7)$ perpustakaan yang tidak lengkap (80\%), (8) kelas terlalu besar $(66,7 \%)$, dan (9) siswa kurang disiplin (60\%) Hassan (2015).

Hasil penelitian sebelumnya yang telah dilakukan oleh para peneliti untuk membelajarkan keterampilan metakognitif siswa. Sukaisih et al. (2020) menerapkan pembelajaran pemecahan masalah dengan strategi konflik kognitif untuk membelajarkan keterampilan metakognitif. Hasil penelitian ini menunjukkan bahwa terjadi peningkatan yang rendah pada keterampilan dalam memeriksa proses pelaksanaan perencanaan (skor 1,10 kategori kurang baik menjadi 2,20 kategori cukup baik), dan keterampilan dalam mengevaluasi hasil (skor 1,12 kategori kurang baik menjadi skor 1,56 kategori cukup baik), dan beberapa keterampilan yang perlu mendapatkan perhatian yaitu membuat perencanan pemecahan masalah dan mengamati proses pelaksanan perencanaan. Pemahaman konsep 
dapat dikembangkan dengan menekankan pada keterlibatan aktivitas kognisi siswa, seperti pembelajaran yang menekankan pada pengembangan keterampilan metakognitif. Pembelajaran yang mengarahkan pada peningkatan metakognitif dapat membantu siswa dalam memperoleh pembelajaran yang bertahan lama dalam ingatan dan pemahamannya (Iskandar, 2016). Berbagai implementasi pembelajaran yang telah dilakukan oleh para peneliti dalam membelajarkan pemahaman konsep dan keterampilan metakognitif siswa. Azhar (2017) mengimplementasikan pembelajaran model penggambaran mikroskopis dengan bantuan pemodelan dapat mengefektifkan proses pembelajaran kimia, namun agar siswa dapat memperoleh pemahaman yang komprehensif, strategi ini perlu ditunjang dengan pendekatan mikroskopik untuk menjelaskan konsep-konsep formal dalam ilmu kimia. Hermansyah et al. (2019) membelajarkan pemahaman konsep siswa menggunakan model pembelajaran inquiry terbimbing dengan laboratorium virtual, hasil penelitian menunjukkan bahwa secara umum dengan model ini lebih efektif meningkatkan pemahaman konsep, namun hal menarik dari hasil penelitian ini adalah pencapaian siswa pada level kognitif dinyatakan baik pada level memorizing (C1) dengan skor 93,0, dan comprehending (C2) dengan skor 95,4, applying (C3) dengan skor 64,0, sedangkan untuk analyzing, evaluating, dan creating mendapatkan skor paling rendag sebesar 12,1; 16,3; dan 3,5. Hasil ini menunjukkan bahwa pembelajaran yang diterapkan belum mampu untuk membawa siswa dalam mencapai tingkatan kognisi yang lebih tinggi secara komprehensif. (Arafah et al., 2020) telah membelajarkan pemahman konsep menggunakan guided inquiry model, diperoleh sebanyak $68,6 \%$ siswa mencapai skor dengan kategori tinggi, dan sebanyak $29 \%$ berkategori kurang baik, sehingga impelementasi model ini perlu secara integrasi agar pemahaman konsep yang dicapai siswa menjadi lebih baik. Nunaki et al. (2019) mengimplementasikan model pembelajaran inquiry, dan efektif untuk membelajarkan keterampilan metakognitif siswa. Gunawan et al. (2019) menerapkan pembelajaran inquiry terbimbing dengan laboratorium virtual untuk membelajarkan keterampilan proses sains siswa, hasil penelitian menunjukkan bahwa pencapaian pemahaman konsep mencapai skor dengan kategori tinggi dan sangat tinggi, namun dari indikator yang diukur, merumuskan masalah mendapatkan skor paling rendah, diikuti kemampuan meringkas.

Implementasi pembelajaran pada penelitian ini adalah model pembelajaran inquiry terbimbing yang diintegrasikan dengan laboratorium virtual berbasis crocodile chemistry untuk membelajarkan pemahaman konsep dan keterampilan metakognisi siswa pada pembelajaran kimia materi larutan penyangga. Pertimbangan dalam implementasi pembelajaran bahwa diperlukan penyajian fenomena secara bervariasi dan kontekstual, siswa memiliki keempatan melakukan percobaan dan secara terintegrasi dengan laboratorium virtual, langkah-langkah pembelajaran meliputi: (1) planning (merencanakan), (2) retrieving (mendapatkan informasi), (3) processing (memproses), (4) creating (membuat laporan hasil), (5) sharing (membagikan informasi), dan (6) evaluating (mengevaluasi). Implementasi pembelajaran inquiry terbimbing terintegrasi laboratorium virtual diharapkan dapat meningkatkan pemahaman konsep dan keterampilan metakognitif siswa, seperti yang telah dilakukan pada penelitian sebelumnya bahwa inquiry terbimbing dengan laboratorium virtual dapat meningkatkan pemahaman konsep siswa (Hermansyah et al., 2019), dan dapat meningkatkan keterampilan proses sains siswa (Gunawan et al., 2019).

Berdasarkan uraian di atas maka permasalahan penelitian ini adalah bagaimanakah pengaruh implementasi model inquiry terbimbing terintegrasi laboratorium virtual terhadap peningkatan pemahaman konsep dan keterampilan metakognitif siswa dalam pembelajaran kimia? Tujuan yang diharapkan dapat dicapai dari penelitian ini adalah implementasi model inquiry terbimbing terintegrasi laboratorium virtual berpengaruh secara signifikan terhadap peningkatan pemahaman konsep dan keterampilan metakognitif siswa pada pembelajaran kimia khususnya materi larutan penyangga.

\section{METODE}

Penelitian ini merupakan penelitian quasi eksperimen dengan menggunakan nonequivalent control group design (Fraenkel et al., 2012) yang dilakukan pada 56 siswa kelas XI IPA SMAN 1 Praya Timur yang terdiri dari 2 (dua) kelas paralel dengan masing-masing 28 orang pada setiap kelas. Pemilihan kelompok eksperimen dan kontrol dilakukan dengan teknik cluster random sampling. Rancangan penelitian disajikan pada Gambar 1. 


\begin{tabular}{cccc|}
\hline Eksperimen & $\mathrm{O}_{1}$ & $\mathrm{X}$ & $\mathrm{O}_{2}$ \\
\hline Kontrol & $\mathrm{O}_{3}$ & - & $\mathrm{O}_{4}$ \\
\hline
\end{tabular}

Gambar 1. Penelitian Quasi Eksperimen dengan nonequivalent control group design

Keterangan:

$O_{1}$ : Hasil pengamatan pada kelompok eksperimen sebelum diberikan perlakuan dengan model pembelajaran inquiry terbimbing terintegrasi laboratorium virtual.

$\mathrm{O}_{2}$ : Hasil pengamatan pada kelompok eksperimen setelah diberikan perlakuan dengan model pembelajaran inquiry terbimbing terintegrasi laboratorium virtual.

$\mathrm{O}_{3} \quad$ : Hasil pengamatan pada kelompok kontrol sebelum dilakukan pembelajaran secara konvensional.

$\mathrm{O}_{4}$ : Hasil pengamatan pada kelompok kontrol setelah dilakukan pembelajaran secara konvensional.

$X$ : Perlakuan pada kelompok eksperimen dengan menerapkan model pembelajaran inquiry terbimbing terintegrasi laboratorium virtual.

Instrumen pada penelitian ini terdiri dari: (1) Tes pemahaman konsep dan (2) lembar penilaian keterampilan metakognitif. Tes pemahaman konsep meliputi indikator: a) menyatakan ulang konsep, b) mengklasifikasi objek-objek menurut sifat-sifat tertentu, c) memberikan contoh dan non contoh dari konsep, dan d) mengaplikasikan konsep atau algoritma pemecahan masalah. Tes pemahaman konsep yang digunakan berupa tes objektif beralasan yang terdiri dari 14 soal materi larutan penyangga yang telah dinyatakan valid dan reliabel. Validitas instrument dari hasil uji coba diperoleh rata-rata nilai $r$-hitung $(0,450)$ lebih besar dari $r_{\text {-tabel }}(0,367)$, sedangkan hasil perhitungan nilai reliabilitas dengan menggunakan rumus alpha cronbach diperoleh nilai $a=0,68$ (kategori tingi), sehingga instrumen dinyatakan valid dan reliabel, serta dapat digunakan untuk mengukur pemahaman konsep siswa. Lembar penilaian keterampilan metakognitif yang digunakan berupa rubrik penilaian keterampilan metakognitif dari hasil kegiatan percobaan yang meliputi: a) merumuskan tujuan umum pembelajaran maupun khusus, b) merumuskan rumusan masalah dan hipotesis, c) membuat perencanaan pemecahan masalah, d) melaksanakan perencanaan secara sistematis, e) mengamati proses pelaksanaan perencanaan secara kelompok dan individu, f) memeriksa proses pelaksanaan perencanaan secara kelompok dan individu, g) mencatat atau mengumpulkan data, dan h) mengevaluasi hasil (Muhali, 2018; Muhali et al., 2019). Hasil ujicoba instrumen lembar penilaian keterampilan metakognitif menunjukkan bahwa secara isi (content validity), konstruk (construct validity), dan muka (face validity) telah dinyatakan valid dengan nilai $r_{a}=0,793 ; 0,840$; dan 0,901 , serta ketiganya leboh besar dari $r_{\text {tabel }}=0,532$, sedangkan perolehan nilai alpha cronbach (a) untuk aspek isi, konten, dan muka sebesar 0,$884 ; 0,913$, dan 0,947 , ketiganya tergolong memiliki reliabilitas sangat tinggi.

Teknik pengumpulan data pada penelitian ini dilakukan dengan menggunakan teknik tes dan teknik penilaian kinerja. Teknik tes digunakan untuk mendapatkan data pemahaman konsep yang diukur sebelum dan setelah pembelajaran. Tes berupa 14 soal objektif beralasan diberikan kepada siswa sebelum pembelajaran (pretest) dan setelah pembelajaran (posttest), yang selanjutnya hasil dari jawaban siswa diolah dengan menggunakan rubrik yaitu: skor 3 (Jawaban Benar - Alasan Benar), skor 2 (Jawaban Benar - Alasan Salah), skor 1 (Jawaban Salah - Alasan Benar), dan skor 0 (awaban Salah - Alasan Salah atau Jawaban Salah Tanpa Alasan dan Tidak Menjajawab). Teknik penilaian kinerja digunakan untuk mendapatkan data keterampilan metakognitif, yang dilakukan dengan menilai kinerja siswa dari hasil pengisian LKP (lembar kerja siswa) pada setiap pertemuan pembelajaran. Penilaian dilakukan menggunakan LP keterampilan metakognitif dengan memberikan tanda pada kolom yang sesuai dengan skor yang dicapai siswa.

Analisis data pemahaman konsep dan keterampilan metakognitif peseerta didik dilakukan dengan menggunakan Persamaan 1.

$P K$ atau $K M=\frac{\text { skor yang diperoleh }}{\text { skor maksimal }} \times 100$.

Keterangan: $P K=$ Pemahaman Konsep, dan $K M=$ Keterampilan metakognitif. 
Nilai pemahaman konsep dan keterampilan metakognitif yang diperoleh selanjutnya dikelompokkan ke dalam kriteria dan kategori sesuai Tabel 1.

Tabel 1. Kriteria dan Kategori Pemahaman Konsep dan Keterampilan Metakognitif Siswa (Muhali, 2021).

\begin{tabular}{cc} 
Nilai & Kategori \\
\hline $80-100$ & Sangat Tinggi \\
$66-79$ & Tinggi \\
$56-65$ & Cukup \\
$40-55$ & Rendah \\
$30-39$ & Sangat Rendah \\
\hline
\end{tabular}

Selanjutnya dilakukan analisis untuk melihat peningkatan yang dicapai sebelum dan setelah pembelajaran pada kedua kelompok, dilakukan dengan menggunakan Uji Normalized Gain (N-Gain) dengan Persamaan 2.

$<G>=\frac{\text { Fpost-Fpre }}{100-\text { Fpre }}$

Keterangan: $\langle G\rangle=\mathrm{N}-$ Gain, Fpost $=$ nilai posttest, dan $F$ pre $=$ nilai pretest .

Perolehan nilai $\mathrm{N}$-Gain selanjutnya dikonversikan ke dalam kriteria seperti pada Tabel 2 (Hake, 1999).

Tabel 2. Nilai dan Kriteria Nilai N-Gain

\begin{tabular}{ccc}
\hline No. & Nilai & Kriteria \\
\hline 1 & $0,7-1,0$ & Tinggi \\
2 & $0,3-0,69$ & Sedang \\
3 & $0,0-0,29$ & Rendah \\
\hline
\end{tabular}

Data nilai pemahaman konsep dan keterampilan metakognitif siswa yang telah dihasiilkan selanjutnya dianalisis secara statistika dengan bantuan SPSS 16.0 for windows.

\section{HASIL DAN PEMBAHASAN}

Penelitian ini bertujuan untuk meningkatkan pemahaman konsep dan keterampilan metakognitif siswa melalui pembelajaran model inquiry terbimbing terintegrasi laboratorium virtual pada pembelajaran kimia materi larutan penyangga. Data yang dihasilkan berupa data pemahaman konsep dan keterampilan metakognitif siswa, selengkapnya dideskripsikan sebagai berikut.

\section{Data Pemahaman Konsep Siswa}

Data pemahaman konsep diperoleh dari hasil tes objektif beralasan yang diberikan sebelum dan setelah pembelajaran pada kelompok eksperimen dan kontrol, hasil tersebut seperti tercantum pada Tabel 3.

Tabel 3. Data Nilai Pemahaman Konsep Siswa

\begin{tabular}{ccccccc}
\hline Kelompok & $\begin{array}{c}\text { Rata-rata } \\
\text { Pretest }\end{array}$ & Kategori & $\begin{array}{c}\text { Rata-rata } \\
\text { Posttest }\end{array}$ & Kategori & $\begin{array}{c}\text { N- } \\
\text { Gain }\end{array}$ & Kategori \\
\hline Eksperimen & 15,14 & $\begin{array}{l}\text { Sangat } \\
\text { rendah }\end{array}$ & 79,15 & Tinggi & 0,76 & Tinggi \\
Kontrol & 14,06 & $\begin{array}{l}\text { Sangat } \\
\text { rendah }\end{array}$ & 43,08 & Rendah & 0,36 & Sedang \\
\hline
\end{tabular}

Data pada Tabel 3 menunjukkan bahwa kelompok eksperimen dan kontrol dilihat dari hasil pretest berada pada level yang sama dengan kategori pemahaman konsep sangat rendah. Setelah implementasi pembelajaran dengan model inquiry terbimbing terintegrasi laboratorium virtual pada kelompok eksperimen, dan pembelajaran konvensional pada kelompok kontrol didapatkan perbedaan peningkatan pemahaman konsep pada kedua kelompok dengan rata-rata 79,15 (kategori tinggi) dan N-Gain 0,76 (kategori tinggi) untuk kelompok eksperimen, dan rata-rata 43,05 (kategori rendah) dan N-Gain 0,36 (kategori sedang) untuk kelompok kontrol. Hal ini berarti model inquiry terbimbing terintegrasi laboratorium virtual lebih efektif untuk meningkatkan pemahaman konsep siswa. 
Hasil analisis data pemahaman konsep siswa sebelum (pretest) dan setelah (posttest) pembelajaran secara statistik dilakukan pada kedua kelompok setelah melalui uji prasyarat. Hasil analisis prasyarat (uji normalitas) untuk data pemahaman konsep sebelum (pretest) dan dan setelah (posttest) pembelajaran menggunakan analisis Kolmogorof-Smirnov dengan bantuan SPSS 16.0 for windows, hasilnya seperti tercantum pada Tabel 4.

Tabel 4. Hasil Analisis Prasyarat (Uji Normalitas) Data Pemahaman Konsep

\begin{tabular}{cccc}
\hline $\begin{array}{c}\text { Data Pemahaman } \\
\text { Konsep }\end{array}$ & Kelompok & $\begin{array}{c}\text { Asymp. Sig (1 } \\
\text { tailed) }\end{array}$ & Kesimpulan \\
\hline Pretest & Eksperimen & 0.002 & tidak normal \\
& Kontrol & 0,001 & tidak normal \\
Posttest & Eksperimen & 0,656 & normal \\
& Kontrol & 0,554 & normal \\
\hline
\end{tabular}

Berdasarkan hasil analisis pada Tabel 4 di atas menunjukkan bahwa data pemahaman konsep siswa sebelum pembelajaran (pretest) tidak terdistribusi normal karena nilai sig. $(\mathrm{p})<$ 0,05 , sehingga analisis selanjutnya menggunakan statistik non parametris (statistik $z$ ) dengan bantuan SPSS 16.0 for windows. Data pemahaman konsep setelah pembelajaran (posttest) dari hasil analisis data pada Tabel 4 menunjukkan bahwa data pemahaman konsep pada kedua kelompok terdistribusi normal, sehingga analisis selanjutnya dilakukan menggunakan statistik parametris (statistika t independent sample t-test) dengan bantuan SPSS 16.0 for windows. Hasil analisis seperti tercantum pada Tabel 5.

Tabel 5. Hasil Analisis Statistik Pemahaman Konsep Siswa Sebelum (Pretest) dan Setelah (Posttest) Pembelajaran

\begin{tabular}{cccc}
\hline Variabel & Data & Sig. $(\boldsymbol{p}), \boldsymbol{a}=\mathbf{0 , 0 5}$ & Alat Analisis \\
\hline Pemahaman Konsep & Pretest & 0,913 & Statistik z \\
& Posttest & 0,000 & Statistik t \\
\hline
\end{tabular}

Berdasarkan hasil analisis statistik pada Tabel 5 di atas, data pretest pemahaman konsep siswa memperoleh nilai sig. $(p)=0,913$ lebih besar dari $a=0,05$, sehingga dapat dinyatakan bahwa tidak terdapat perbedaan antara pemahaman konsep siswa pada materi larutan penyangga pada kelompok eksperimen dan kelompok kontrol. Analisis data posttest menunjukkan bahwa nilai sig. $(p)=0,000$, lebih kecil dari $a=0,05$, sehingga dapat dikatakan bahwa terdapat perbedaan antara pemahaman konsep siswa pada kelompok eksperimen yang dibelajarkan menggunakan model inquiry terbimbing terintegrasi laboratorium virtual dengan pemahaman konsep kelompok kontrol yang dibelajarkan secara konvensional. Hal ini mengindikasikan bahwa secara statistik penerapan model inquiry terintegrasi laboratorium virtual memiliki pengaruh yang signifikan terhadap pemahaman konsep siswa dalam pembelajaran kimia materi larutan penyangga. Hasil ini sesuai dengan hasil penelitian yang dilakukan (Hermansyah et al., 2019) bahwa inquiry terbimbing dengan laboratorium virtual efektif untuk meningkatkan pemahaman konsep, dan peningkatan tersebut yang lebih baik pada kelompok eksperimen dari pada kelompok kontrol.

\section{Data Keterampilan Metakognitif Siswa}

Data keterampilan metakognitif didapat dengan menggunakan lembar penilaian keterampilan metakognitif yang diukur pada setiap pertemuan pembelajaran yang tercermin dari kinerja siswa dalam LKP. Rata-rata hasil penilaian keterampilan metakognitif pada setiap pertemuan pembelajaran seperti tercantum pada Tabel 6 berikut ini.

Tabel 6. Rata-rata Keterampilan Metakognitif (KM) Siswa pada Setiap Pertemuan Pembelajaran

\begin{tabular}{|c|c|c|c|c|c|}
\hline \multirow{2}{*}{ Kelompok } & \multicolumn{3}{|c|}{ Rata-rata KM pada Pertemuan ke- } & \multirow[b]{2}{*}{ Rata-rata } & \multirow[b]{2}{*}{ Kategori } \\
\hline & I & II & III & & \\
\hline $\begin{array}{l}\text { Eksperimen } \\
\text { Kontrol }\end{array}$ & $\begin{array}{l}54,69 \\
46,09\end{array}$ & $\begin{array}{l}67,86 \\
53,01\end{array}$ & $\begin{array}{l}79,24 \\
55,13\end{array}$ & $\begin{array}{l}67,26 \\
51,41\end{array}$ & $\begin{array}{l}\text { Tinggi } \\
\text { Cukup }\end{array}$ \\
\hline
\end{tabular}

Berdasarkan data pada Tabel 6 tersebut menunjukkan terdapat peningkatan keterampilan metakognitif siswa pada setiap pertemuan pembelajaran. Peningkatan 
keterampilan metakognitif pada kelompok eksperimen lebih baik dibandingkan peningkatan pada kelompok kontrol. Hal ini berarti bahwa pembelajaran dengan model inquiry terbimbing terintegrasi laboratorium virtual lebih baik dalam meningkatkan keterampilan metakognitif siswa daripada dengan pembelajaran konvensional seperti yang diterapkan pada keompok kontrol. Hasil ini sesuai dengan hasil penelitian (Gunawan et al., 2019), model inquiry melalui laboratorium dapat meningkatkan keterampilan proses sains siswa, dan terbukti memberikan pengaruh yang signifikan. Data keterampilan metakognitif siswa pada masing-masing indikator pada kelompok eksperimen dan kontrol pada setiap pertemuan pembelajaran disajikan pada Tabel 7.

Tabel 7. Data Keterampilan Metakognitif pada Setiap Indikator di Setiap Pertemuan Pembelajaran

\begin{tabular}{|c|c|c|c|c|c|c|c|c|c|}
\hline \multirow[t]{2}{*}{ No. } & \multirow[t]{2}{*}{ Indikator } & \multicolumn{3}{|c|}{$\begin{array}{c}\text { Rata-rata Kelompok } \\
\text { Eksperimen pada } \\
\text { Pertemuan ke- }\end{array}$} & \multirow[t]{2}{*}{$\begin{array}{l}\text { Rata- } \\
\text { rata }\end{array}$} & \multicolumn{3}{|c|}{$\begin{array}{c}\text { Rata-rata Kelompok } \\
\text { Kontrol pada } \\
\text { Pertemuan ke- } \\
\end{array}$} & \multirow[t]{2}{*}{$\begin{array}{l}\text { Rata- } \\
\text { rata }\end{array}$} \\
\hline & & I & II & III & & I & II & III & \\
\hline 1. & $\begin{array}{l}\text { Menyatakan } \\
\text { tujuan umum dan } \\
\text { khusus }\end{array}$ & 25,00 & 39,29 & 58,93 & 41,07 & 25,00 & 25,00 & 27,68 & 25,89 \\
\hline 2. & $\begin{array}{l}\text { Merumuskan } \\
\text { masalah dan } \\
\text { hipotesis }\end{array}$ & 61,61 & 63,39 & 66,07 & 63,69 & 25,00 & 25,00 & 25,00 & 25,00 \\
\hline 3. & $\begin{array}{l}\text { Membuat } \\
\text { perencanaan }\end{array}$ & 50,00 & 71,43 & 75,00 & 65,48 & 25,00 & 25,00 & 25,00 & 25,00 \\
\hline 4. & $\begin{array}{l}\text { Melaksanakan } \\
\text { perencanaan }\end{array}$ & 59,82 & 75,00 & 100,00 & 78,27 & 55,36 & 75,00 & 75,00 & 68,45 \\
\hline 5. & $\begin{array}{l}\text { Mengamati } \\
\text { proses } \\
\text { pelaksanaan } \\
\text { rencana }\end{array}$ & 70,54 & 69,64 & 75,00 & 71,73 & 50,00 & 68,75 & 75,00 & 64,58 \\
\hline 6. & $\begin{array}{l}\text { Memeriksa } \\
\text { proses } \\
\text { pelaksanaan } \\
\text { rencana }\end{array}$ & 66,07 & 75,00 & 75,00 & 72,02 & 68,75 & 70,54 & 75,00 & 71,43 \\
\hline 7. & $\begin{array}{l}\text { Membuat catatan/ } \\
\text { mengumpulkan } \\
\text { data }\end{array}$ & 50,00 & 69,64 & 96,43 & 72,02 & 69,64 & 70,54 & 75,00 & 71,73 \\
\hline 8. & $\begin{array}{l}\text { Mengevaluasi } \\
\text { hasil }\end{array}$ & 54,46 & 79,46 & 87,50 & 73,81 & 50,00 & 64,29 & 63,39 & 59,23 \\
\hline
\end{tabular}

Berdasarkan data pada Tabel 7, pada kelompok eksperimen pencapaian kinerja siswa pada setiap indikator selama 3 (tiga) kali pertemuan pembelajaran mengalami peningkatan, sama halnya pada kelompok kontrol. Data rata-rata keterampilan metakognitif siswa pada kelompok eksperimen lebih baik dari kelompok kontrol, namun perbedaan rata-rata pada indikator 6 (memeriksa proses pelaksanaan rencana), dan indikator 7 (mengumpulkan data) mencapai rata-rata yang hampir sama, artinya baik pada kelompok eksperimen maupun kontrol kedua indikator ini sama-sama dilakukan dengan baik. Kelemahan dari kedua kelompok adalah pada indikator 1 (menyatakan tujuan umum dan khusus), indikator 2 (merumuskan masalah dan hipotesis, dan indikator 3 (membuat perencanaan) dengan pencapaian rata-rata paling rendah dari indikator lainnya, Gunawan et al. (2019) merumuskan masalah dan hipotesis secara rata-rata keduanya mencapai hasil paling rendah dari pada indikator lain, Perbedaan rata-rata yang paling tampak pada kedua kelompok adalah pada indikator 4 (melaksanakan perencanaan), indikator 5 (mengamati proses pelaksanaan rencana), indikator 7 (mengevaluasi hasil). Yang ketiganya merupakan indikator penting dalam proses p[elaksanaan percobaan. Menurut (Gunawan et al., 2019) keterampilan dalam melakukan praktek atau percobaan mencapai rata-rata paling tinggi daripada indikator yang lain. 
Implementasi model inquiry terbimbing terintegrasi laboratorium virtual memberikan pengaruh yang signifikan terhadap pemahaman konsep dan keterampilan metakognitif siswa dalam pembelajaran kimia materi larutan penyangga. Deskripsi pengaruh dari implementasi tersebut dijelaskan sebagai berikut.

\section{Pengaruh Model Pembelajaran Inquiry Terbimbing Terintegrasi Laboratorium Virtual Terhadap Pemahaman Konsep Siswa}

Berdasarkan hasil analisis statistik, didapat nilai signifikansi $<0,05$, hal ini menunjukkan bahwa ada perbedaan signifikan pemahaman konsep kelas eksperimen dan kelas kontrol. Jadi, dapat dinyatakan bahwa ada pengaruh model inquiry terbimbing terintegrasi laboratorium virtual terhadap pemahaman konsep siswa. Rata-rata pemahaman konsep kelas eksperimen lebih baik dibandingkan rata-rata pemahaman konsep kelas kontrol. Perbedaan pemahaman konsep kelas eksperimen dan kelas kontrol dikarenakan oleh pembelajaran yang dilakukan dapat menarik minat siswa selama proses pembelajaran melalui penggunaan laboratorium virtual. Penggunaan media pembelajaran yang menarik selama proses pembelajaran melalui visualisasi dan praktik akan mengaktikan proses berpikir siswa. Menurut Jones (2018) laboratorium virtual merupakan platform yang berisi simulasi eksperimen laboratorium dan dipicu dari jarak jauh yang memungkinkan siswa mempelajari konsep ilmiah yang mengatur eksperimen dengan mudah melalui visualisasi dan praktik.

Perbedaan pemahaman konsep kelas eksperimen dan kelas kontrol selain dikarenakan oleh penggunaan media pembelajaran yang efektif, juga dikarenakan oleh model pembelajaran inkuiri yang diterapkan. Model pembelajaran inkuiri akan memberikan kesempatan pada siswa untuk dapat melakukan kontruksi konsepnya sendiri, sehingga pemahaman akan konsep materi yang dibelajarkan bertahan lebih lama. Inkuiri terbimbing menuntut siswa dapat melakukan kegiatan berpikir seperti perumusan masalah dan pengujian hipotesis yang dikemukakan, yang berdampak pada aktifnya siswa dalam membangun konsepnya sendiri. Penggunaan media pembelajaran seperti laboratorium virtual dapat menarik minat siswa selama proses pembelajaran (Argandi et al., 2013), efektif untuk meningkatkan hasil belajar siswa (Mulyatun, 2012), memberikan pengaruh yang signifikan terhadap pemahaman konsep siswa (Hermansyah et al., 2019).

\section{Pengaruh Model Pembelajaran Inquiry Terbimbing Terintegrasi Laboratorium Virtual Terhadap Keterampilan Metakognitif Siswa}

Keterampilan metakognitif pada kelompok eksperimen lebih baik dibandingkan keterampilan metakognitif kelompok kontrol, dilihat dari rata-rata skor yang dicapai siswa pada kedua kelompok tersebut. Hal tersebut sebagai akibat dari implementasi model inquiry terbimbing terintegrasi laboratorium virtual. Pencapaian keterampilan metakognitif siswa (Tabel 7) pada indikator 1 (menyatakan tujuan), 2 (merumuskan masalah dan hipotesis), dan 3 (membuat perencanaan), lebih baik pada kelompok eksperimen lebih baik dari kelompok kontrol, hal ini disebabkan karena pembelajaran inquiry terbimbing terintegrasi laboratorium memberikan kesempatan kepada siswa dalam membuat perencanaan dengan lebih baik, dan memfokuskan siswa terhadap yang dipelajari. Menurut Fitriana dan Haryani (2016), pembelajaran inquiry merangsang siswa untuk melakukan pemecahan masalah, sehingga siswa dapat lebih memahami tujuan pembelajaran, sehingga memacu dalam melakukan proses kontrol maupun evaluasi pembelajaran.

Proses pengontrolan pembelajaran pada siswa sesuai data pada Tabel 7 dilihat dari indikator 4, 5, 6, dan 7 juga terdapat perbedaan pada kedua kelompok baik ekepserimen maupun kontrol. Hal ini mengindikasikan bahwa pembelajaran inquiry terbimbing terintegrasi laboratorium virtual memberikan kesempatan mendapatkan informasi dengan lebih efisien, juga menyadarkan siswa akan kontrol berpikirnya, sehingga tahu apa yang dilakukan dan bagaimana melakukannya. Hunaepi et al. (2020) menyatakan bahwa dengan pembelajaran inquiry siswa mampu mengontrol secara aktif proses kognitifnya.

Berdasarkan data pada Tabel 7, sekalipun terdapat perbedaan aspek kontrol (indikator $4,5,6,7)$ kedua kelas tidaklah berbeda jauh. Kelas kontrol memiliki kesadaran untuk mengontrol proses kognisinya. Hal ini disebabkan oleh pembelajaran yang dilakukan sekalipun menggunakan pembelajaran konvensional, namun menggunakan pendekatan saintifik. Pembelajaran konvensional yang digunakan yaitu diskusi dan ceramah atau 
pembelajaran langsung dapat meningkatkan keterampilan metakognitif dikarenakan pembelajaran yang dilakukan menggunakan bahan ajar yang disesuaikan dengan pendekatan saintifik dan memberikan instruksi yang jelas. Menurut Fitriana dan Haryani (2016) bahwa pembelajaran dengan pendekatan saintifik dapat meningkatkan keterampilan metakognitif melalui penguasaan konsep tahap demi tahap pada pembelajaran.

Aspek keterampilan metakognitif selanjutnya yaitu evaluasi pembelajaran (indikator 8), pada Tabel 7 dapat dilihat bahwa rata-rata aspek evaluasi pembelajaran kelas eksperimen lebih baik dibandingkan kelas kontrol. Hal ini disebabkan oleh kelas eksperimen memiliki perencanaan yang lebih baik dibandingkan kontrol. Perencanaan yang lebih baik membuat siswa lebih sadar akan proses berpikir yang dilakukannya. Hal ini sesuai dengan penelitian yang dilakukan oleh Iskandar (2016) bahwa keterampilan metakognitif yang tinggi dapat dilakukan dengan melakukan perencanaan pembelajaran yang baik.

Secara umum, rata-rata peningkatan keterampilan metakognitif kelas eksperimen lebih tinggi dibandingkan kelas kontrol (Tabel 6). Hal ini disebabkan oleh pembelajaran yang dilakukan di kelas ekperimen menekankan pada pembelajaran aktif dan pengembangan keterampilan berpikir. Hal ini sesuai dengan pendapat Asy'ari et al. (2019) yang menyimpulkan bahwa keterampilan metakognitif dapat dilatih melalui pemecahan masalah dan aktivitas kerja ilmiah. Irawati et al. (2020) menyatakan pembelajaran inkuiri memberikan keterampilan metakognitif yang baik melalui proses penemuan yang dilakukannya.

\section{KESIMPULAN}

Berdasarkan hasil dan pembahasan maka kesimpulan dari penelitian ini yaitu (1) model pembelajaran inquiry terbimbing terintegrasi laboratorium virtual memberikan pengaruh yang signifikan terhadap pemahaman konsep siswa dalam pembelajaran kimia materi larutan penyangga. Hal ini dilihat dari perolehan rata-rata pemahaman konsep siswa pada kelompok eksperimen sebesar 15,14 (pretest) dan 79,15 (posttest), dengan N-gain 0,76 (kategori tinggi), sedangkan kelompok kontrol sebesar 14,06 (pretest) dan 43,08 (posttest) dengan N-gain 0,36 (kategori sedang). Hasil uji statistika menggunakan statistik $\mathrm{t}$ (independent sample $t$-tes) diperoleh nilai sig. $=0,000$; (2) Model pembelajaran inquiry terbimbing terintegrasi laboratorium virtual dapat meningkatkan keterampilan metakognitif siswa dalam pembelajaran kimia materi larutan penyangga. Peningkatan tersebut dapat dilihat dari rata-rata keterampilan metakognitif kedua kelompok di setiap pertemuan, kelompok eksperimen sebesar 54,69 (pertemuan I), 67,86 (pertemuan II), dan 79,24 (pertemuan III), sedangkan kelompok kontrol sebesar 46,09 (pertemuan I), 53,01 (pertemuan II), dan 55,13 (pertemuan III).

\section{REKOMENDASI}

Berdasarkan temuan pada penelitian ini maka dapat direkomendasikan hal-hal sebagai berikut: (1) Model inquiry terbimbing terintegrasi laboratorium virtual dalam implementasinya dalam pembelajaran hendaknya didukung dengan bahan ajar yang lebih menekankan siswa dapat menyatakan tujuan baik secara umum maupun khusus, merumuskan masalah dan menyusu hipotesis dengan benar, dan dapat membuat perencanaan dengan benar dengan sistematis, sehingga memberikan dampak pada peningkatan pemahaman konsep dan keterampilan metakognitif dengan baik; (2) Implementasi model inquiry terbimbing sebaiknya mengarah pada masalah yang lebih kontekstual, dan pengintegrasian laboratorium virtual lebih mengarah pada pembuktian konsep dari hasil/data yang diperoleh siswa melalui serangkaian langkah-langkah model inquiry terbimbing.

\section{DAFTAR PUSTAKA}

Adnyana, G. P. (2012). Keterampilan Berpikir Kritis dan Pemahaman Konsep Siswa pada Model Siklus Belajar Hipotetis Deduktif. Jurnal Pendidikan Dan Pengajaran, 45(3), Article 3. https://doi.org/10.23887/jppundiksha.v45i3.1833

Arafah, K., Rusyadi, R., Arafah, B., Arafah, A., \& Arafah, B. (2020). The Effect of Guided Inquiry Model and Learning Motivation on the Understanding of Physics Concepts. Talent Development and Excellence, 12, 4271-4283.

Argandi, R., Martini, K. S., \& Catur Saputro, A. N. (2013). Pembelajaran Kimia Dengan Metode Inquiry Terbimbing Dilengkapi Kegiatan Laboratorium Real Dan Virtual Pada Pokok 
Bahasan Pemisahan Campuran. Jurnal Pendidikan Kimia Universitas Sebelas Maret, 2(2), 44-49.

Asy'ari, M., Hidayat, S., \& Muhali, M. (2019). Prototipe buku ajar fisika dasar reflektif-integratif berbasis problem solving untuk meningkatkan pengetahuan metakognisi. Jurnal Inovasi Pendidikan IPA, 5(2). https://doi.org/10.21831/jipi.v5i2.27089

Azhar, A. (2017). Keefektifan Pembelajaran Konsep Kimia Larutan dengan Menerapkan Model Penggambaran Mikroskopis di Man Kabupaten Pidie. Lantanida Journal, 5(1), 73-82. https://doi.org/10.22373/lj.v5i1.2060

Fitriana, M., \& Haryani, S. (2016). Penggunaan strategi pembelajaran inkuiri untuk meningkatkan metakognisi siswa sma. Jurnal Inovasi Pendidikan Kimia, 10(1), Article 1. https://doi.org/10.15294/jipk.v10i1.6016

Fraenkel, J. R., Wallen, N. E., \& Hyun, H. H. (2012). How to design and evaluate research in education (8th ed). McGraw-Hill Humanities/Social Sciences/Languages.

Gunawan, G., Harjono, A., Hermansyah, H., \& Herayanti, L. (2019). Guided inquiry model through virtual laboratory to enhance students' science process skills on heat concept. Cakrawala Pendidikan, 38(2), 259-268. https://doi.org/10.21831/cp.v38i2.23345

Hake, R. R. (1999). Analyzing Change/Gain Scores*. 4.

Hassan, A. (2015). Factors-affecting-students-performance-in-chemistry-case-study-inzanzibar-secondary-schools.

Hendriek Nunaki, J., Damopolii, I., Kandowangko, N., \& Nusantari, E. (2019). The Effectiveness of Inquiry-based Learning to Train the Students' Metacognitive Skills Based on Gender Differences. International Journal of Instruction, 12, 505-516. https://doi.org/10.29333/iji.2019.12232a

Hermansyah, H., Gunawan, G., Harjono, A., \& Adawiyah, R. (2019). Guided inquiry model with virtual labs to improve students' understanding on heat concept. Journal of Physics: Conference Series, 1153, 012116. https://doi.org/10.1088/17426596/1153/1/012116

Hunaepi, H., Firdaus, L., Samsuri, T., Susantini, E., \& Raharjo, R. (2020). Efektifitas Perangat Pembelajaran Inkuiri Terintegrasi Kearifan Lokal Terhadap Keterampilan Berpikir Kritis Mahasiswa. Scholaria: Jurnal Pendidikan Dan Kebudayaan, 10(3), 269-281. https://doi.org/10.24246/j.js.2020.v10.i3.p269-281

Irawati, N., Setyowati, W. A. E., \& Mulyani, S. (2020). Penerapan Model Pembelajaran Inkuiri Terbimbing Dilengkapi LKS untuk Meningkatkan Kemampuan Berpikir Kritis dan Prestasi Belajar Siswa pada Materi Pokok Reaksi Reduksi-Oksidasi Kelas X MIA SMA Islam 1 Surakarta Tahun Pelajaran 2017/2018. Jurnal Pendidikan Kimia, 9(1), 1-10. https://doi.org/10.20961/jpkim.v9i1.28836

Iskandar, S. M. (2016). Pendekatan keterampilan metakognitif dalam pembelajaran sains di kelas. Erudio Journal of Educational Innovation, 2(2), 13-20.

Jones, N. (2018). Simulated labs are booming. Nature, 562(7725), S5-S7. https://doi.org/10.1038/d41586-018-06831-1

Kemendikbud. (2013). Peraturan Menteri Pendidikan dan Kebudayaan Republik Indonesia Nomor $54 \quad$ Tahun $2013 . \quad$ Kemendikbud. https://akhmadsudrajat.files.wordpress.com/2013/06/01-b-salinan-lampiranpermendikbud-no-54-tahun-2013-ttg-skl.pdf

Muhali, M. (2018). Pengembangan Model Pembelajaran Reflektif-Metakognitif untuk Meningkatkan Kemampuan Metakognisi Siswa SMA (Developement of ReflectiveMetacognitive Learning Model to Improve High School Students' Metacognition Ability).

Muhali, M. (2019). Pembelajaran Inovatif Abad Ke-21. Jurnal Penelitian Dan Pengkajian IImu Pendidikan: E-Saintika, 3(2), 25. https://doi.org/10.36312/e-saintika.v3i2.126

Muhali, M. (2021). Pengaruh Implementasi Model Creative Problem Solving terhadap Peningkatan Kemampuan Pemecahan Masalah, Keterampilan Proses Sains, dan Kesadaran Metakognisi Peserta Didik. Lensa: Jurnal Kependidikan Fisika, 9(1), 4557. https://doi.org/10.33394/j-lkf.v9i1.4261

Muhali, M., Asy'ari, M., \& Sukaisih, R. (2020). Analisis Kemampuan Regulasi Kognisi Peserta Didik dalam Pembelajaran. Empiricism Journal, 1(2), 51-59. https://doi.org/10.36312/ej.v1i2.333 
Muhali, M., Yuanita, L., \& Yuanita, L. (2019). The Validity and Effectiveness of the ReflectiveMetacognitive Learning Model to Improve Students' Metacognition Ability in Indonesia. Malaysian Journal of Learning and Instruction, 16(Number 2). https://doi.org/10.32890/mjli2019.16.2.2

Mulyatun, M. (2012). Laboratorium kimia virtual: Alternatif pembelajaran kimia untuk meningkatkan hasil belajar mahasiswa tadris kimia IAIN Walisongo Semarang. Jurnal Inovasi Pendidikan Kimia, 6(2), Article 2. https://doi.org/10.15294/jipk.v6i2.6530

Sudria, I. B. N., Redhana, I. W., \& Samiasih, L. (2011). Pengaruh pembelajaran interaktif laju reaksi berbantuan komputer terhadap hasil belajar siswa. Jurnal Pendidikan Dan Pengajaran, 44(1), Article 1. https://doi.org/10.23887/jppundiksha.v44i1.135

Sukaisih, R., \& Muhali, M. (2014). Meningkatkan kesadaran metakognitif dan hasil belajar siswa melalui penerapan pembelajaran problem solving. Prisma Sains: Jurnal Pengkajian IImu Dan Pembelajaran Matematika Dan IPA IKIP Mataram, 2(1), 71. https://doi.org/10.33394/j-ps.v2i1.803

Sukaisih, R., Muhali, M., \& Asy'ari, M. (2020). Meningkatkan keterampilan metakognisi dan berpikir kritis siswa melalui pembelajaran model pemecahan masalah dengan strategi konflik-kognitif. Empiricism Journal, 1(1), 37-50. https://doi.org/10.36312/ej.v1i1.329

Sukmawati, W. (2019). Analisis level makroskopis, mikroskopis dan simbolik mahasiswa dalam memahami elektrokimia. Jurnal Inovasi Pendidikan IPA, 5. https://doi.org/10.21831/jipi.v5i2.27517 